\title{
Evaluation of an inexpensive needle test for the diagnosis of phosphorus deficiency and management of phosphorus supplementation for cattle: A multiple case study
}

\author{
PEDRO MALAFAIA ${ }^{1}$, FELIPE Z. GARCIA ${ }^{2}$, SAMARA P. LOPES ${ }^{2}$, VINÍCIUS C. SOUZA ${ }^{3}$, \\ CAMILLO F.C. CANELLA FILHO ${ }^{4}$, DIOGO F.A. COSTA ${ }^{5}$ and CRISTIANO C.P. VEIGA ${ }^{6}$ \\ ${ }^{1}$ Departamento de Nutrição Animal e Pastagens, Universidade Federal Rural do Rio \\ de Janeiro, BR 465, Km 7, 23854-150 Seropédica, RJ, Brazil \\ ${ }^{2}$ Programa de Pós-Graduação em Zootecnia, Universidade Federal Rural do Rio \\ de Janeiro, BR 465, Km 7, 23854-150 Seropédica, RJ, Brazil \\ ${ }^{3}$ Departamento de Zootecnia, Universidade Estadual Paulista, Campus Jaboticabal, Rod. \\ Professor Paulo Donato Castellane, Km 5, 14884-900 Jaboticabal, SP, Brazil \\ ${ }^{4}$ Universidade do Vale do Rio Verde, Av. Castelo Branco, 82, 37410-000 Três Corações, MG, Brazil \\ ${ }^{5}$ Beef Cattle Research Center, Kansas State University, College Avenue, 3115, 66506 Manhattan, KS, USA \\ ${ }^{6}$ Setor de Diagnóstico por Imagens, Hospital Veterinário, Universidade Federal Rural \\ do Rio de Janeiro, BR 465, Km 7, 23854-150 Seropédica, RJ, Brazil
}

Manuscript received on September 1, 2017; accepted for publication on January 22, 2018

\begin{abstract}
The needle test (NT) is a point-of-care test developed in Brazil to evaluate the Phosphorus (P) status in cattle. Based on bone resistance, the NT is a very inexpensive method which allows the diagnosis of any degree of P deficiency in a fast and simple way in vivo and directly on farm. The NT measures three levels of resistance in the transverse process (TP) of the lumbar vertebrae: a) TP that are impenetrable and result in warping of the needle (P healthy animals); b) TP offering some resistance to the penetration (animals with subclinical P deficiency); and c) TP which has minimal resistance to penetration (clinical P deficiency). This manuscript presents results from a series of case studies to evaluate the hypothesis that the NT could be used to assess P status in cattle and assesses the usefulness of results to support decision making on mineral supplementation strategies for grazing cattle. The NT was able to detect the changes in the resistance patterns of the TP, as there was reduction or elevation of P levels in the mineral mixtures. The NT was useful to assist in decision-making for adoption of mineral supplementation strategies better suited for each farm, helping farmers to save money and avoid unnecessary waste of $\mathrm{P}$.
\end{abstract}

Key words: Beef and dairy cattle, Phosphorus, mineral deficiency, mineral supplementation.

\section{INTRODUCTION}

Cattle production in Brazil is conducted predominantly on tropical pastures with moderate

Correspondence to: Pedro Malafaia

E-mail: malafaia_ufrrj@yahoo.com.br to low soil fertility. The predominant grasses are of the genus Urochloa (Brachiaria), which are able to grow on the low phosphorus (P) content of the soil. The subsequent low $\mathrm{P}$ content of the forage may result in subclinical or clinical $\mathrm{P}$ deficiencies in cattle (Tokarnia et al. 2010, Malafaia et al. 2014). 
Clinical $\mathrm{P}$ deficiency results in considerable economic losses due to spontaneous fractures, postural deviations that compromise locomotion, significantly reduces fertility rate and weight gain, and the possibility of botulism secondary to osteophagia (Tokarnia and Döbereiner 1973). On farm, the diagnosis of clinical P deficiency in cattle is relatively easy to perform; however, this cannot be said about more discrete deficiency states, which occur with signs common to many other health problems of cattle, such as poor weight gain and suboptimal fertility rate (Suttle 2010, Tokarnia et al. 2010). Subclinical deficiency of $P$ most likely affects the majority of cattle raised exclusively on pastures in Brazil and causes considerable economic losses every year (Malafaia et al. 2014).

Existing methods for the diagnosis of $\mathrm{P}$ deficiency involve chemical analysis of $\mathrm{P}$ in soil, forage, blood, faeces, and in bone (Read et al. 1986, Suttle 2010, Jackson et al. 2012), bone specific gravity measurements by Archimedes principle (Little 1972), bone mineral density estimation through radiographs of $12^{\text {th }}$ samples of ribs coupled with an aluminum step wedge (Malafaia et al. 2017, Souza et al. 2017) or by single photon absorptiometry (Murray et al. 1994, Coates et al. 2015). These methods are time consuming, inaccurate and/or imprecise, invasive, expensive and because of their technical sophistication not easily done on farm. Therefore, under Brazilian conditions, the producers usually have no access to reliable information on the actual $\mathrm{P}$ status of their cattle, which contributes to the widespread misuse of commercial mineral supplements (CMS) with high P levels (Malafaia et al. 2014).

Prior to adoption of mineral supplements, a detailed history and a careful clinical examination of the herd should be conducted and a simple, rapid and cheap method must be used to establish the $\mathrm{P}$ status of the cattle (Malafaia et al. 2014). This would indicate the correct concentration of $\mathrm{P}$ in a mineral supplement. The needle test (NT) proposed by Diomedes Barbosa, and quoted by Tokarnia et al. (2010), allows the diagnosis of P deficiency (clinical or subclinical) in a fast, cheap and simple way done in vivo directly on farm. In this context, the NT can be considered a point-of-care (POC) test. Nevertheless, this test has not been conducted before to evaluate mineral supplementation strategies for cattle.

Case studies should be conducted to investigate complex environments, held in natural contexts and applied to contemporary matters, trying where that is possible to be combined with other scientific approaches, such as the experimental method utilized in the current paper. This approach called meta-method is ideal for applications in fieldoriented studies. Results presented in this paper were obtained during long-term experiments that followed the considerations above and aimed to use the NT to evaluate P status and to assist in decisions about different $\mathrm{P}$ supplementation schemes in beef and dairy farms in Brazil.

\section{MATERIALS AND METHODS}

A series of case studies were carried out on six farms across various regions of Brazil (case A, $\mathrm{B}, \mathrm{C}, \mathrm{D}, \mathrm{E}$ and $\mathrm{F}$ ) and in one research project at Universidade Estadual de São Paulo (UNESP), Jaboticabal Campus. On all sites the NT was performed on 9 to 50 adult cattle, along with data on herd history. Rib samples were collected from healthy and clinical or subclinical P-deficient beef and dairy cattle for further lab analysis. All properties received technical assistance throughout the experimental period.

\section{CASE DESCRIPTIONS}

\section{Case A}

São Pedro do Rochedo is a beef ranch located at Conservatória, RJ $\left(22^{\circ} 13^{`} 07 \mathrm{~S} ; 4^{\circ} 56^{`} 44 \mathrm{~W}\right)$ with a herd of about 430 Nellore cows that had received for several years a CMS mixed with 
elevated amounts of sodium chloride. Many cows showed osteophagia from December 2014 to March 2015 in field observations. A total of 58 cows died with a clinical signs such as isolation from the herd, reluctance to move, slow reaction, progressive paresis, being unable to stand, severe emaciation, and staying alert until death. Clinical signs resembled those of botulism. Cattle were not vaccinated against botulism and infection could have resulted from osteophagia, since carcasses were not removed from pasture. The soil $\mathrm{pH}$ and $\mathrm{P}$ concentration of the grassland area, collected from the upper $20 \mathrm{~cm}$, were 5.4 and $4.8 \mathrm{mg} / \mathrm{dm}^{3}$. The cows had a body condition score of 4.5 , based on the grading system (1 to 9) for beef cattle Nicholson and Butterworth (1986), and the fertility rate was $56 \%$. A new mineral supplementation scheme based on the herd diagnosis was established on April 2015 (Table I).
Case B

Santana ranch is located at Valença, RJ $\left(22^{\circ} 17^{`} 59 \mathrm{~S}\right.$; $43^{\circ} 4657 \mathrm{~W}$ ) and is comprised of about 550 Nellore cows that had received a CMS with $75 \mathrm{~g} \mathrm{P} / \mathrm{kg}$ for several years. The main concern of the owner was the high annual expenditure with this CMS. Field observation did not show evidence of any mineral deficiency. Clinical examination revealed adequate $\mathrm{P}$ status and there was no history of osteophagia; the fertility rate was $78 \%$ and the average of the weight at weaning was $184 \mathrm{~kg}$ at 8 months of age. Two composite soil samples, collected from the upper 20 $\mathrm{cm}$ of grassland, resulted in 3.2 and $2.6 \mathrm{mg} \mathrm{P} / \mathrm{dm}^{3}$ and $\mathrm{pH}$ of 5.3 and 4.6, respectively. Based on these findings a new mineral supplementation scheme was introduced in December 2013 (Table II).

TABLE I

Data of São Pedro do Rochedo farm using experimental procedures to determine the most suitable mineral supplementation criteria.

\begin{tabular}{|c|c|c|c|c|c|c|}
\hline & Until 4/4/15 & $\begin{array}{c}\text { From } 4 / 5 / 15 \text { to } \\
9 / 5 / 15\end{array}$ & $\begin{array}{c}\text { From } 9 / 6 / 15 \text { to } \\
12 / 11 / 15\end{array}$ & $\begin{array}{l}\text { From } 12 / 12 / 15 \\
\text { to } 4 / 10 / 16\end{array}$ & $\begin{array}{l}\text { From } 4 / 11 / 16 \\
\text { to } 8 / 13 / 16\end{array}$ & $\begin{array}{c}\text { From } 8 / 13 / 16 \\
\text { to } 1 / 28 / 17\end{array}$ \\
\hline Supplement used & $\begin{array}{c}25 \mathrm{~kg} \\
\text { Commercial } \\
\text { mineral } \\
\text { supplement } \\
\text { containing } 40 \mathrm{~g} \\
\mathrm{P} / \mathrm{kg}+50 \mathrm{~kg} \\
\mathrm{NaCl}\end{array}$ & $\begin{array}{c}100 \mathrm{~kg} \mathrm{NaCl} \\
+50 \mathrm{~kg} \text { Single } \\
\text { superphosphate } \\
+200 \mathrm{~g} \mathrm{Cu}_{2} \mathrm{SO}_{4}\end{array}$ & $\begin{array}{c}150 \mathrm{~kg} \mathrm{NaCl} \\
+50 \mathrm{~kg} \mathrm{Single} \\
\text { superphosphate } \\
+200 \mathrm{~g} \mathrm{Cu}_{2} \mathrm{SO}_{4}\end{array}$ & $\begin{array}{c}150 \mathrm{~kg} \mathrm{NaCl} \\
+50 \mathrm{~kg} \mathrm{Single} \\
\text { superphosphate } \\
+200 \mathrm{~g} \mathrm{Cu}_{2} \mathrm{SO}_{4}\end{array}$ & $\begin{array}{c}100 \mathrm{~kg} \mathrm{NaCl} \\
+50 \mathrm{~kg} \text { Single } \\
\text { superphosphate } \\
+200 \mathrm{~g} \mathrm{Cu}_{2} \mathrm{SO}_{4}\end{array}$ & $\begin{array}{c}100 \mathrm{~kg} \mathrm{NaCl} \\
+50 \mathrm{~kg} \mathrm{Single} \\
\text { superphosphate } \\
+200 \mathrm{~g} \mathrm{Cu}_{2} \mathrm{SO}_{4}\end{array}$ \\
\hline $\begin{array}{c}\mathrm{P}(\mathrm{g} / \mathrm{kg} \text { of } \\
\text { supplement) }\end{array}$ & 13.3 & 28 & 21 & 21 & 28 & 28 \\
\hline Positive cows ${ }^{*}, \#$ & $10(52.6 \%)$ & 0 & $1(7.2 \%)$ & $1(5.3)$ & 0 & 0 \\
\hline Negative cows ${ }^{*, \#}$ & $9(47.4 \%)$ & $19(100 \%)$ & $13(92.8)$ & $18(94.7)$ & $16(100 \%)$ & $12(100 \%)$ \\
\hline Osteophagia ${ }^{*}$ & yes & no & no & no & no & no \\
\hline Diagnosis or status & Clinical & Healthy & Subclinical & Subclinical & Healthy & Healthy \\
\hline $\mathrm{CT}(\mathrm{mm})^{*}$ & $\begin{array}{c}2.39 \pm 0.18 \\
\quad(n=8)\end{array}$ & $\begin{array}{c}3.89 \pm 0.31 \\
\quad(n=6)\end{array}$ & $\begin{array}{c}3.15 \pm 0.36 \\
\quad(n=6)\end{array}$ & $\begin{array}{c}3.21 \pm 0.39 \\
\quad(n=6)\end{array}$ & $\begin{array}{c}3.47 \pm 0.28 \\
\quad(n=6)\end{array}$ & $\begin{array}{c}3.39 \pm 0.21 \\
\quad(n=6)\end{array}$ \\
\hline $\mathrm{BSG}(\mathrm{g} / \mathrm{cm})^{*}$ & $\begin{array}{c}1.28 \pm 0.22 \\
(\mathrm{n}=8)\end{array}$ & $\begin{array}{c}1.47 \pm 0.13 \\
(\mathrm{n}=6)\end{array}$ & $\begin{array}{l}1.42 \pm 0.17 \\
(\mathrm{n}=6)\end{array}$ & $\begin{array}{c}1.37 \pm 0.11 \\
(\mathrm{n}=6)\end{array}$ & $\begin{array}{l}1.51 \pm 0.19 \\
(\mathrm{n}=6)\end{array}$ & $\begin{array}{c}1.48 \pm 0.20 \\
(\mathrm{n}=6)\end{array}$ \\
\hline $\mathrm{BMD}(\mathrm{mm} \mathrm{Al})^{*}$ & $\begin{array}{c}3.42 \pm 0.42 \\
\quad(n=8)\end{array}$ & $\begin{array}{c}4.56 \pm 0.58 \\
\quad(n=6)\end{array}$ & $\begin{array}{c}4.06 \pm 0.49 \\
(n=6)\end{array}$ & $\begin{array}{c}4.34 \pm 0.43 \\
\quad(n=6)\end{array}$ & $\begin{array}{c}4.25 \pm 0.51 \\
\quad(n=6)\end{array}$ & $\begin{array}{c}4.38 \pm 0.46 \\
\quad(n=6)\end{array}$ \\
\hline $\begin{array}{c}\text { Monthly } \\
\text { expenditure (R\$) }\end{array}$ & 574 & 403 & 435 & 467 & 421 & 476 \\
\hline
\end{tabular}

*Evaluated on 4/4/15, 9/5/15, 12/11/15, 4/10/16 and 8/13/16. $\mathrm{n}=$ number of animals biopsied. $\mathrm{CT}=$ Cortical thickness; $\mathrm{BSG}=$ Bone specific gravity; $\mathrm{BMD}=$ Bone mineral density.

\#by the needle test. 
TABLE II

Data of Santana farm using experimental procedures to determine the most suitable mineral supplementation criteria.

\begin{tabular}{|c|c|c|c|c|c|c|c|}
\hline & $\begin{array}{c}\text { Until } \\
12 / 9 / 13\end{array}$ & $\begin{array}{l}\text { From } 12 / 10 / 13 \\
\text { to } 5 / 22 / 14\end{array}$ & $\begin{array}{l}\text { From } \\
5 / 23 / 14 \text { to } \\
10 / 12 / 14^{\mathrm{a}}\end{array}$ & $\begin{array}{l}\text { From } 10 / 13 / 14 \\
\text { to } 6 / 30 / 15\end{array}$ & $\begin{array}{l}\text { From } \\
6 / 31 / 15 \text { to } \\
10 / 1 / 15\end{array}$ & $\begin{array}{l}\text { From } 10 / 1 / 15 \\
\text { to } 6 / 10 / 16\end{array}$ & $\begin{array}{c}\text { From } \\
6 / 10 / 16 \text { to } \\
10 / 17 / 16\end{array}$ \\
\hline $\begin{array}{l}\text { Supplement } \\
\text { used }\end{array}$ & $\begin{array}{c}\text { Commercial } \\
\text { mineral } \\
\text { supplement }\end{array}$ & $\begin{array}{l}100 \mathrm{~kg} \mathrm{NaCl}+ \\
17,5 \mathrm{~kg} \mathrm{Single} \\
\text { superphosphate } \\
+300 \mathrm{~g} \mathrm{Cu}_{2} \mathrm{SO}_{4} \\
+50 \mathrm{~g} \mathrm{CoSO}_{4}\end{array}$ & $\begin{array}{l}\text { protein } \\
\text { supplement } \\
+\mathrm{NaCl}\end{array}$ & $\begin{array}{l}100 \mathrm{~kg} \mathrm{NaCl}+ \\
17,5 \mathrm{~kg} \mathrm{Single} \\
\text { superphosphate } \\
+300 \mathrm{~g} \mathrm{Cu}_{2} \mathrm{SO}_{4} \\
+50 \mathrm{~g} \mathrm{CoSO}_{4}\end{array}$ & $\begin{array}{l}\text { protein } \\
\text { supplement } \\
+\mathrm{NaCl}\end{array}$ & $\begin{array}{l}100 \mathrm{~kg} \mathrm{NaCl}+ \\
17,5 \mathrm{~kg} \mathrm{Single} \\
\text { superphosphate } \\
+300 \mathrm{~g} \mathrm{Cu}_{2} \mathrm{SO}_{4} \\
+50 \mathrm{~g} \mathrm{CoSO}_{4}\end{array}$ & $\begin{array}{l}\text { protein } \\
\text { supplement } \\
+\mathrm{NaCl}\end{array}$ \\
\hline $\begin{array}{c}\mathrm{P}(\mathrm{g} / \mathrm{kg} \text { of } \\
\text { supplement })\end{array}$ & 75 & 12.5 & 0 & 12.5 & 0 & 12.5 & 0 \\
\hline Positive cows ${ }^{*}, \#$ & 0 & 0 & 0 & 0 & 0 & 0 & 0 \\
\hline $\begin{array}{c}\text { Negative } \\
\text { cows }\end{array}$ & $14(100 \%)$ & $13(100 \%)$ & $10(100 \%)$ & $11(100 \%)$ & $11(100 \%)$ & $15(100 \%)$ & $11(100 \%)$ \\
\hline Osteophagia $^{*}$ & no & no & no & no & no & no & no \\
\hline $\begin{array}{c}\text { Diagnosis or } \\
\text { status }\end{array}$ & Healthy & Healthy & Healthy & Healthy & Healthy & Healthy & Healthy \\
\hline $\mathrm{CT}(\mathrm{mm})$ & nd & nd & nd & $\begin{array}{c}3.65 \pm 0.31 \\
\quad(n=3)\end{array}$ & $\begin{array}{c}4.04 \pm 0.27 \\
\quad(n=3)\end{array}$ & nd & $\begin{array}{c}3.59 \pm 0.38 \\
\quad(n=3)\end{array}$ \\
\hline $\mathrm{BSG}(\mathrm{g} / \mathrm{cm})$ & nd & nd & nd & $\begin{array}{c}1.46 \pm 0.11 \\
(\mathrm{n}=3)\end{array}$ & $\begin{array}{c}1.56 \pm 0.18 \\
(\mathrm{n}=3)\end{array}$ & nd & $\begin{array}{c}1.56 \pm 0.22 \\
(\mathrm{n}=3)\end{array}$ \\
\hline $\mathrm{BMD}(\mathrm{mm} \mathrm{Al})$ & nd & nd & nd & $\begin{array}{c}4.75 \pm 0.79 \\
(\mathrm{n}=3)\end{array}$ & $\begin{array}{l}4.83 \pm 0.58 \\
(n=3)\end{array}$ & nd & $\begin{array}{l}4.51 \pm 0.54 \\
\quad(n=3)\end{array}$ \\
\hline $\begin{array}{l}\text { Monthly } \\
\text { expenditure } \\
\text { (R\$) }\end{array}$ & 1568 & 370 & 194 & 422 & 183 & 381 & 194 \\
\hline $\begin{array}{c}\text { Fertility rate } \\
(\%)\end{array}$ & 76.4 & & 78.5 & & 72.1 & & 85.0 \\
\hline
\end{tabular}

${ }^{a}$ During dry season only $\mathrm{NaCl}$ was offered to the herd. $\mathrm{n}=$ number of animals biopsied.

*Evaluated on 12/9/13, 5/22/14, 10/12/14, 6/17/15, 10/17/15, 4/18/16 and 9/17/16.

$\mathrm{CT}=$ Cortical thickness; $\mathrm{BSG}=$ Bone specific gravity; BMD $=$ Bone mineral density.

"by the needle test.

nd - not determined.

Case C

Paraíso ranch is a dairy farm also situated at

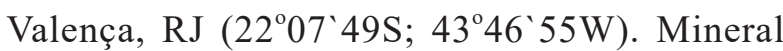
supplementation was provided for several years with a CMS containing $75 \mathrm{~g} \mathrm{P} / \mathrm{kg}$. Similar to case $\mathrm{B}$, the main concern of the owner was the high monthly costs related to CMS supplement. There were no signs of osteophagia and the body condition score was 3.0, using the grading system (1 to 5) (Edmondson et al. 1989). Average milk production and fertility rate was $12.4 \mathrm{~kg} / \mathrm{cow} /$ day and $67 \%$, respectively. Examination of composite soil samples (20 cm depth), resulted in $11 \mathrm{mg} \mathrm{P} / \mathrm{dm}^{3}$ and $\mathrm{pH}$ of 5.6, respectively. After the first visit and a clinical-nutritional examination, supplementation with only $\mathrm{NaCl}$ was recommended and established in April 2013 (Table III).

\section{Case D}

João e Maria farm is situated at Seropédica, RJ $\left(22^{\circ} 47^{`} 10 \mathrm{~S} ; 43^{\circ} 4450 \mathrm{~W}\right)$ where annually 14 to 16 cross breed dairy heifers are raised. Animals are bought at weaning (150-180 kg) and sold when pregnant $(350-400 \mathrm{~kg})$. The farm does not use any type of CMS, and the heifers are raised only on pasture (Cynodon spp. and Panicum spp.), which was established after two years of a rotational intensive crop system with okra and cowpea. Analysis of composite soil samples (20 cm depth) 
TABLE III

Data of Paraíso farm using experimental procedures to determine the most suitable mineral supplementation criteria.

\begin{tabular}{|c|c|c|c|c|}
\hline & Until 4/20/13 & $\begin{array}{c}\text { From } 4 / 21 / 14 \text { to } \\
8 / 17 / 14\end{array}$ & $\begin{array}{c}\text { From } 8 / 18 / 14 \text { to } \\
9 / 19 / 15\end{array}$ & $\begin{array}{c}\text { From } 10 / 20 / 15 \text { to } \\
10 / 15 / 16\end{array}$ \\
\hline Supplement used & $\begin{array}{c}\text { Commercial mineral } \\
\text { supplement }\end{array}$ & $\mathrm{NaCl}$ & $\begin{array}{c}70 \mathrm{~kg} \mathrm{NaCl}+30 \mathrm{~kg} \\
\text { Single superphosphate }\end{array}$ & $\mathrm{NaCl}$ \\
\hline $\mathrm{P}$ (g/kg of supplement) & 75 & 0 & 25.5 & 0 \\
\hline $\begin{array}{l}\text { Milk production }(\mathrm{kg} / \mathrm{cow} / \\
\text { day })^{*}\end{array}$ & 12.4 & 13.7 & 13.1 & 13.9 \\
\hline Positive cows ${ }^{*, \#}$ & 0 & $2(12.5 \%)$ & 0 & 0 \\
\hline Negative cows ${ }^{*, \#}$ & $16(100 \%)$ & $14(87.5 \%)$ & $16(100 \%)$ & $20(100 \%)$ \\
\hline Osteophagia ${ }^{*}$ & no & yes & no & no \\
\hline Diagnosis or status & Healthy & Clinical & Healthy & Healthy \\
\hline $\mathrm{CT}(\mathrm{mm})$ & nd & $3.14 \pm 0.28(\mathrm{n}=3)$ & $4.87 \pm 0.44(\mathrm{n}=3)$ & nd \\
\hline BSG $(\mathrm{g} / \mathrm{cm})$ & nd & $1.29 \pm 0.14(\mathrm{n}=3)$ & $1.53 \pm 0.16(n=3)$ & nd \\
\hline $\mathrm{BMD}(\mathrm{mm} \mathrm{Al})$ & nd & $4.25 \pm 0.39(n=3)$ & $6.00 \pm 0.58(n=3)$ & nd \\
\hline Monthly expenditure (R\$) & 254.0 & 35.0 & 68.5 & nd \\
\hline
\end{tabular}

*Evaluated on 4/20/13,8/17/14, 9/19/15, and 10/15/16. $\mathrm{n}=$ number of animals biopsied.

$\mathrm{CT}=$ Cortical thickness; $\mathrm{BSG}=$ Bone specific gravity; $\mathrm{BMD}=$ Bone mineral density.

\#Needle test.

nd - not determined.

TABLE IV

Data of João e Maria farm using experimental procedures to determine the most suitable mineral supplementation criteria.

\begin{tabular}{|c|c|c|c|c|}
\hline & $\begin{array}{c}\text { From } 5 / 2 / 13 \text { to } \\
12 / 30 / 13\end{array}$ & $\begin{array}{c}\text { From } 12 / 31 / 13 \text { to } \\
5 / 7 / 14\end{array}$ & $\begin{array}{c}\text { From } 5 / 8 / 14 \text { to } \\
11 / 30 / 14\end{array}$ & $\begin{array}{c}\text { From } 11 / 31 / 14 \text { to } \\
5 / 27 / 15\end{array}$ \\
\hline Supplement used & $\mathrm{NaCl}$ & $\mathrm{NaCl}$ & $\mathrm{NaCl}$ & $\mathrm{NaCl}$ \\
\hline $\mathrm{P}(\mathrm{g} / \mathrm{kg}$ of supplement) & 0 & 0 & 0 & 0 \\
\hline Positive heifers ${ }^{*, \#}$ & 0 & 0 & 0 & 0 \\
\hline Negative heifers ${ }^{*}, \#$ & $10(100 \%)$ & $9(100 \%)$ & $9(100 \%)$ & $11(100 \%)$ \\
\hline Osteophagia ${ }^{*}$ & no & no & no & no \\
\hline Diagnosis or status & Healthy & Healthy & Healthy & Healthy \\
\hline $\mathrm{CT}(\mathrm{mm})$ & $2.94 \pm 0.11(\mathrm{n}=4)$ & $3.13 \pm 0.28(\mathrm{n}=3)$ & $2.89 \pm 0.36(n=3)$ & $3.07 \pm 0.31(\mathrm{n}=3)$ \\
\hline BSG (g/cm) & $1.42 \pm 0.10(\mathrm{n}=4)$ & $1.46 \pm 0.22(\mathrm{n}=3)$ & $1.57 \pm 0.27(\mathrm{n}=3)$ & $1.38 \pm 0.19(\mathrm{n}=3)$ \\
\hline $\mathrm{BMD}(\mathrm{mm} \mathrm{Al})$ & $3.41 \pm 0.41(n=4)$ & $3.75 \pm 0.30(n=3)$ & $3.75 \pm 0.39(n=3)$ & $3.50 \pm 0.46(n=3)$ \\
\hline Monthly expenditure (R\$) & 3.53 & 4.21 & 4.12 & 4.35 \\
\hline
\end{tabular}

*Evaluated on $5 / 2 / 13,5 / 7 / 14,11 / 30 / 14$, and 3/27/15. $\mathrm{n}=$ number of animals biopsied. $\mathrm{CT}=$ Cortical thickness; $\mathrm{BSG}=$ Bone specific gravity; $\mathrm{BMD}=$ Bone mineral density.

\#by the needle test.

resulted in 3.8 and $5.2 \mathrm{mg} \mathrm{P} / \mathrm{dm}^{3}$ and $\mathrm{pH}$ of 5.3 and 5.7, respectively before and after cropping. No osteophagia and adequate $\mathrm{P}$ status was observed in all heifers examined. Based on results from clinical-nutritional examination a fit-for-purpose mineral supplementation scheme was implemented in May 2013, using only $\mathrm{NaCl}$ (Table IV).

\section{Case E and Case F}

Serrador ranch, Varginha, MG (2130`12S; $44^{\circ} 27^{`} 33 \mathrm{~W}$ ) and Barreiro ranch, Três Corações, MG $\left(21^{\circ} 3647 \mathrm{~S} ; 45^{\circ} 16^{\prime} 13 \mathrm{~W}\right)$, respectively. Herds from both ranches consisted of approximately 170 and 120 lactating dairy cows, respectively. Animals were fed 
TABLE V

Data of Serrador and Barreiro farms using experimental procedures to determine the most suitable mineral supplementation criteria.

\begin{tabular}{|c|c|c|c|c|}
\hline & $\begin{array}{c}\text { Case } \\
\text { E From } 3 / 2 / 2004 \text { to } \\
4 / 22 / 15\end{array}$ & $\begin{array}{c}\text { Case E } \\
\text { From } 4 / 23 / 15 \\
\text { to } 8 / 17 / 16\end{array}$ & $\begin{array}{c}\text { Case } F \\
\text { From } 1 / 8 / 13 \text { to } \\
4 / 22 / 15\end{array}$ & $\begin{array}{c}\text { Case } F \\
\text { From } 4 / 3 / 15 \text { to } \\
8 / 17 / 16\end{array}$ \\
\hline Supplement used & $\begin{array}{c}100 \mathrm{~kg} \mathrm{NaCl}+250 \mathrm{~g} \\
\mathrm{Cu}_{2} \mathrm{SO}_{4}+40 \mathrm{~g} \mathrm{CoSO}\end{array}$ & $\begin{array}{c}100 \mathrm{~kg} \mathrm{NaCl}+250 \mathrm{~g} \\
\mathrm{Cu}_{2} \mathrm{SO}_{4}+40 \mathrm{~g} \mathrm{CoSO}_{4}\end{array}$ & $\begin{array}{c}100 \mathrm{~kg} \mathrm{NaCl}+250 \mathrm{~g} \\
\mathrm{Cu}_{2} \mathrm{SO}_{4}+40 \mathrm{~g} \mathrm{CoSO}_{4}\end{array}$ & $\begin{array}{c}100 \mathrm{~kg} \mathrm{NaCl}+250 \mathrm{~g} \\
\mathrm{Cu}_{2} \mathrm{SO}_{4}+40 \mathrm{~g} \mathrm{CoSO}_{4}\end{array}$ \\
\hline $\mathrm{P}$ (g/kg of supplement) & 0 & 0 & 0 & 0 \\
\hline Positive cows ${ }^{*, \#}$ & 0 & 0 & 0 & 0 \\
\hline Negative cows ${ }^{*, \#}$ & $11(100 \%)$ & $10(100 \%)$ & $10(100 \%)$ & $9(100 \%)$ \\
\hline $\begin{array}{l}\text { Milk production } \\
\text { day })^{*}\end{array}$ & 17.8 & 18.7 & 21.3 & 18.6 \\
\hline Osteophagia $^{*}$ & no & no & no & no \\
\hline Diagnosis or status & Healthy & Healthy & Healthy & Healthy \\
\hline $\mathrm{CT}(\mathrm{mm})$ & $3.68 \pm 0.61(n=3)$ & $3.47 \pm 0.48(\mathrm{n}=3)$ & $3.49 \pm 0.51(n=3)$ & $3.54 \pm 0.42(\mathrm{n}=3)$ \\
\hline BSG $(\mathrm{g} / \mathrm{cm})$ & $1.52 \pm 0.16(\mathrm{n}=3)$ & $1.58 \pm 0.28(n=3)$ & $1.56 \pm 0.31(\mathrm{n}=3)$ & $1.49 \pm 0.36(\mathrm{n}=3)$ \\
\hline $\mathrm{BMD}(\mathrm{mm} \mathrm{Al})$ & $5.58 \pm 0.67(n=3)$ & $5.23 \pm 0.72(\mathrm{n}=3)$ & $5.67 \pm 0.58(\mathrm{n}=3)$ & $5.14 \pm 0.61(n=3)$ \\
\hline Monthly expenditure (R\$) & 297 & 304 & 243 & 267 \\
\hline
\end{tabular}

*Evaluated on 4/22/15 and 8/17/16 (Case E) and on 1/8/13 and 8/17/16. $n=$ number of animals biopsied.

$\mathrm{CT}=$ Cortical thickness; $\mathrm{BSG}=$ Bone specific gravity; $\mathrm{BMD}=$ Bone mineral density.

${ }^{\#}$ By the needle test.

according to NRC (2001) recommendations. After clinical and nutritional examinations, the $\mathrm{P}$ status of both herds was considered in excess. On both farms the concentrate consisted of soybean meal, whole cotton seed, ground corn, citrus pulp and a mineral mix, which resulted in a daily amount of 4 to $7 \mathrm{~kg}$ /lactating cow. On both farms, $25-30 \mathrm{~kg}$ of corn silage was fed daily per cow in the morning, after the first milking. Between the first and second milking, cows had access to paddocks of either Urochloa brizantha or Panicum maximum (cv. Tanzânia), that were fertilized with NPK mixture based on yearly soil analyses. Based on results from herd diagnosis a new mineral supplementation scheme using only $\mathrm{NaCl}$, Copper $(\mathrm{Cu})$, and Cobalt (Co) was established in March 2004 (Case E, Table V) and on January 2013 (Case F, Table V).

\section{Case $G$ (Research experiment)}

The study was conducted at the Universidade Estadual de São Paulo (UNESP), School of Agricultural and Veterinarian Sciences, Jaboticabal
Campus, SP $\left(21^{\circ} 14^{`} 12 \mathrm{~S} ; 48^{\circ} 17^{`} 40 \mathrm{~W}\right)$. Prior to the start of the experiment, fifty Nellore bulls (initial $\mathrm{BW}=296 \pm 25 \mathrm{~kg}$ ) were kept for 49 days (from $06 / 08 / 14$ to $07 / 28 / 14$ ) on a pasture of Urochloa brizantha cv. Xaraés, supplemented only with sodium chloride. This procedure was necessary to minimize any possible effects of $\mathrm{P}$ intake from the commercial mineral supplementation used at the farm from where they had been purchased. Subsequently, eight animals were slaughtered to obtain reference data for bone parameters and all bulls were submitted to the NT. The remaining 42 bulls were confined for 116 days with a diet containing $80 \%$ concentrate and $20 \%$ roughage on a dry matter (DM) basis. Animals were distributed into three groups, where the variable was $\mathrm{P}$ content in the total diets. Fourteen bulls (group 1) received no extra $\mathrm{P}$ with a mineral supplement ( $\mathrm{P}$ intake was only that contained in the roughage and in the concentrate, and the final concentration was $0.24 \%$ $\mathrm{P}$ in the DM). Another 14 bulls (group 2) were $\mathrm{P}$ supplemented with a mineral premix recommended 
by the Brazilian industry for mineral supplements for feedlot cattle and the diet had $0.42 \% \mathrm{P}$ in the DM. The remaining 14 animals (group 3) were supplemented with a similar amount of $\mathrm{P}$, but through the use of dicalcium phosphate without adding other additives (ionophores, yeast, and microminerals) contained in the mineral mix used in group 2; the final P concentration was $0.50 \%$ in the DM. Regarding the P status groups, 2 and 3 were considered reference standard. The study lasted 116 days, similar to commercial feedlot cattle in Brazil. The hypothesis was that when feedlot cattle ingest high grain proportions, no supplemental $\mathrm{P}$ is required. To investigate the effect of different daily intakes of $\mathrm{P}$ on bone quality, rib biopsies were taken from three bulls from each experimental group on day 30, 60 and 90. At the beginning of the experiment rib biopsies from three animals were randomly taken for reference values. On the day of slaughter, three rib samples were collected from randomly selected animals within treatments to represent each experimental group. Thus, a total of 36 rib biopsies were performed throughout the experimental period. On the same days of biopsies, all animals were submitted to NT. These results have already been published by Souza et al. (2016, 2017).

\section{BONE EVALUATIONS}

Cattle were physically restrained in the crush before the NT or rib biopsy. For the NT, a 40x1.2 needle $\left(18 \mathrm{G} \times 1^{1 / 2}\right)$ needle was inserted through the skin, subcutaneous and muscle tissue until it reached the transverse process (TP) of the lumbar vertebrae $\mathrm{L}_{2}$ or $\mathrm{L}_{3}$ (Tokarnia et al. 2010). Once positioned about halfway of the TP, the operator pushes on the needle gun using a finger trying to penetrate the needle across the cortical layer of the lumbar vertebrae. Three TP resistance patterns are established: a) TP that are impenetrable and result in warping of the needle (P adequate status); b) TP offering some resistance to the penetration, resulting in use of great effort by the operator to pierce the TP (animals with some degree of P deficiency often subclinical); c) TP which has minimal resistance to penetration of the needle (animals with clinical P deficiency). The results of the NT were described as positive (e.g. clinical or subclinical status) when a TP was pierced through, and negative (no deficient) if the needle warped after pressed against the TP. All animals were observed closely to evaluate if the NT would cause any trauma or infection. The positive or negative cases were described as $\%$ of the total of animals examined on each visit. Scores were given for NT results, where $1=$ cattle with clinical $\mathrm{P}$ deficiency, $2=$ with subclinical $\mathrm{P}$ deficiency and 3 for $\mathrm{P}$ adequate cattle.

The rib samples were collected to obtain samples of a circular shape, with bone average weight of $3 \mathrm{~g}$ (Malafaia et al. 2017). Rib samples were stored in clean plastic bags and frozen at $-20^{\circ} \mathrm{C}$. Rib cortical thickness (CT) was measured with an electronic caliper. The bone specific gravity (BSG) of the rib samples was obtained based on Archimedes principle of ratio between mass and volume of the bone sample. Initially, the rib sample was thawed, cleaned and blot-dried with a paper towel and weighed using a four decimal precision scale, then $50 \mathrm{~mL}$ of distilled water was added to a $100 \mathrm{~mL}$ beaker and the bone sample was gently put inside. The elevation of the water column was measured using a digital caliper. The displaced water volume was calculated by the formula: Volume $=\pi \cdot r^{2} \cdot h$; where: $\pi=3.14 ; \mathrm{r}=$ internal radius of the beaker (mm); $\mathrm{h}=$ height of water column displaced ( $\mathrm{mm}$ ).

For the assessment of bone mineral density (BMD), rib samples were dried and placed under a photographic film, all in the same position, and then radiographed beside an aluminum step wedge with 25 steps, whose heights (thickness) are 0.25 $\mathrm{mm}$ between steps 1 to $22,1 \mathrm{~mm}$ from step 23 to step 25 (Souza et al. 2017). We used a digital X-ray 
model OEC 9900 Elite Series GE OEC Medical Systems, calibrated, with focus-film distance of 90 $\mathrm{cm}$, set to $60 \mathrm{kVp}, 10 \mathrm{~mA}$ and exposure time of 0.10 second. The digital radiographs were saved in JPEG format and the histogram tool of Corel Photo Paint X4 software was used to estimate bone mineral density. For the measurement of BMD, the average pixel values of each rib sample were converted to values relating to thickness of each step of the aluminum scale (mmAL).

\section{STATISTICAL ANALYSIS}

Since multiple case studies do not have true replications nor casualization, hypothesis tests were not conducted for any variables in this paper. Because of the herd management of the farms, cows were not the same within evaluations (e.g. end of breeding season for fertility rate (FR) or each visit for NT), therefore, data on FR and the results of NT were described as percentages. The scores of NT (1, 2 and 3) were plotted against the average of bone parameters (CT, BSG and BMD). For bone parameters all means were described together with a confidence interval (CI) of $95 \%$. The estimation of CI was presented as follows: $\mu_{\mathrm{x}} \pm$ $(\mathrm{U}-\mathrm{L}) / 2$; Where $\mu$ is the mean of a variable, $\mathrm{x}$; and $\mathrm{U}$ and $\mathrm{L}$ are the upper and lower limits of the $95 \%$ confidence interval, respectively. The interpretation of economic data was made by comparing annual costs, considering the use of both types of mineral mixtures (CMS or the new supplementation criteria).

\section{ETHICAL APPROVAL}

The rib biopsies and the needle tests were approved by the ethics committee on the use of human and animal subjects in teaching and research of the Universidade Federal Rural do Rio de Janeiro (UFRRJ) and by human and animal care and handling procedures, according to guidelines of UNESP (under protocol 7741/14).

\section{RESULTS}

\section{CASE A}

On the first visit (4/4/15), the herd was receiving a commercial mineral supplement containing $13.3 \mathrm{~g} \mathrm{P} / \mathrm{kg}$ and many cows were seen performing osteophagia. Fifty three percent of the cows were positive (the needle penetrated in TP) for the NT, which was conducted on animals that had less than two months after calving. The CT, BSG, and BMD of the $12^{\text {th }}$ rib were $2.39,1.28$ e 3.42 (Table I). After increasing the P levels in the supplement to $28 \mathrm{~g} / \mathrm{kg}$, (from $4 / 5$ until 9/5/15) the values were increased to $3.89,1.47$, and 4.56 for $\mathrm{CT}$, BSG and BMD, respectively, and no animals were positive for the NT. From 9/6/15 until 4/10/16, as a cost reduction approach, we decided to use a formula with $21 \mathrm{~g} \mathrm{P} /$ $\mathrm{kg}$; during this period, two evaluations were made and approximately 5 to $7 \%$ of cows were positive for the NT (Table I). Despite no osteophagia being observed, from 4/11/16 until the present day, the adopted formula was again up to $28 \mathrm{~g} \mathrm{P} / \mathrm{kg}$ and no more cows produced positive results in the NT, or presented signs of osteophagia.

\section{CASE B}

On the first visit (12/9/13) the commercial mineral supplement used contained $75 \mathrm{~g} \mathrm{P} / \mathrm{kg}$ and no cow with less than two months after calving expressed any signs of osteophagia or was positive for the NT. Herd history and clinical examination of various animals did not indicate the necessity to perform rib biopsies to assess bone characteristics (Table II). From 12/10/13 to 5/22/14 (rainy season) the farm started using a supplement with $12.5 \mathrm{~g} \mathrm{P} /$ $\mathrm{kg}$. During the dry season of the following year, $5 / 23 / 14$ until 10/12/14, the herd was fed a protein supplement prepared on farm, using ground corn, soybean meal and $\mathrm{NaCl}$ with no addition of $\mathrm{P}$. No cows were positive in the NT during the whole experimental period where they were supplemented 
with $12.5 \mathrm{~g} \mathrm{P} / \mathrm{kg}$. Rib biopsies were collected $10 / 13 / 14,6 / 31 / 15$ and $6 / 10 / 16$ to evaluate bone parameters. Results varied between 3.59 to 4.04 , 1.46 to 1.56 , and 4.51 to 4.83 , respectively for CT, BSG and BMD (Table II). Since 12/10/13, the farm had only used a supplement with $12.5 \mathrm{~g} \mathrm{P} / \mathrm{kg}$ during the rainy season and a protein supplement during the dry season. When the herd was supplemented with CMS the fertility rate (FR) was $76.4 \%$ and this value was considered as reference for comparison with the FR values obtained during the three years of the experimental period, which had an average of $78.6 \%$ (Table II). Adoption of the new mineral supplementation scheme resulted in an estimated cost reduction in the order $420 \%$ compared to the total spent with commercial supplements previously used.

\section{CASE C}

At the first visit, on $4 / 20 / 13$, the herd was supplemented with a commercial mineral supplement that had $75 \mathrm{~g} \mathrm{P} / \mathrm{kg}$, no animals exhibited signs of osteophagia and none of the tested cows was positive in the NT (Table III). Therefore, no rib biopsies were collected at this time. However, by using exclusively $\mathrm{NaCl}$ as mineral supplement from $4 / 21 / 13$ to $8 / 17 / 14$ it was observed that some cows started performing osteophagia without any apparent reductions in fertility or milk production. On the next visit, on $8 / 17 / 14$, cases of osteophagia were confirmed and $12.5 \%$ of animals were positive in the NT. Therefore, rib biopsies were performed and values were obtained for CT, BSG and BMD of $3.14,1.29$, and 4.25 , respectively (Table III). During our visit the milk producer informed that he had decided to use a high amount of citrus pulp ( $4-6 \mathrm{~kg} / \mathrm{cow} /$ day) in order to reduce feeding costs. The estimation of daily dry matter and calcium intake were $13.4 \mathrm{~kg}$ and $116.8 \mathrm{~g}$ per cow, respectively, which resulted in an average concentration of $\mathrm{Ca}$ of $0.87 \%$ in the diet. Citrus pulp is an ingredient rich in calcium and poor in $\mathrm{P}$; so we suggested to change the concentrate formula to one that would be balanced in protein, energy and P. A new mineral formula containing $25.5 \mathrm{~g} \mathrm{P} /$ $\mathrm{kg}$ was suggested on $8 / 18 / 14$. About a year later on $9 / 19 / 15$ new rib samples were again collected to obtain new bone parameters which were 4.87 , 1.53 , and 6.00, respectively, for CT, BSG and BMD (Table III). No more signs of osteophagia or animals positive with the NT were observed (Table III). Since 10/20/15 the farm has only used $\mathrm{NaCl}$ as a mineral supplement and no more cows have presented positive results for the NT (Table III).

\section{CASE D}

On 5/2/13, after a clinical and nutritional evaluation, the heifers received only $\mathrm{NaCl}$ as mineral supplement. Until then no animals had exhibited signs of osteophagia or were positive in the NT, with values of CT, BSG, and BMD of 2.94, 1.42 and 3.41, respectively, for rib samples collected in 5/2/13 (Table IV). After two years of assessment, no osteophagia or positive heifers in the NT were observed. On 5/27/15, bone parameters for CT, BSG, and BMD were 3.07, 1.35 and 3.50 , respectively (Table IV). From 5/2/13 until $5 / 27 / 15$ the farm used exclusively $\mathrm{NaCl}$ as a mineral supplement and no animal was positive in the NT (Table IV). Over two years the average daily weight gain was $416 \mathrm{~g} \pm 127 \mathrm{SEM}$.

CASE E

From 3/2/2004 to $4 / 22 / 15$ the farm had not used any mineral supplements containing $\mathrm{P}$, no signs of osteophagia were observed and no cows were positive in the NT. On $4 / 22 / 15$, the CT, BSG and the BMD were $3.68,1.52$, and 5.58, respectively (Table V). Repeatedly no signs of osteophagia or positive results in the NT were observed from 4/22/15 until 8/17/16. On 8/17/16, CT, BSG, and BMD were $3.47,1.58$ and 5.23, respectively 
TABLE VI

Data of experimental case using experimental procedures to determine the most suitable mineral supplementation criteria for feedlot bulls.

\begin{tabular}{|c|c|c|c|c|}
\hline & $\begin{array}{l}\text { From } 6 / 8 / 14 \text { to } \\
7 / 28 / 14\left(\mathrm{n}=50^{1}\right)\end{array}$ & $\begin{array}{l}\text { From } 7 / 29 / 14 \text { to } \\
11 / 28 / 14(n=14)\end{array}$ & $\begin{array}{l}\text { From } 7 / 29 / 14 \text { to } \\
11 / 28 / 14(n=14)\end{array}$ & $\begin{array}{l}\text { From } 7 / 29 / 14 \text { to } \\
11 / 28 / 14(n=14)\end{array}$ \\
\hline Supplement used & $\mathrm{NaCl}$ & $\mathrm{NaCl}$ & Dicalcium phosphate & $\begin{array}{l}\text { Commercial mineral } \\
\text { supplement }\end{array}$ \\
\hline P (g/kg Dry Matter) & nd & 2.3 & 4.2 & 5.0 \\
\hline Positive bulls ${ }^{*, \#}$ & $3(6 \%)$ & 0 & 0 & 0 \\
\hline Negative bulls ${ }^{*, \#}$ & $47(94 \%)$ & $14(100 \%)$ & $14(100 \%)$ & $14(100 \%)$ \\
\hline Diagnosis or status & Subclinical & Healthy & Healthy & Healthy \\
\hline $\mathrm{CT}(\mathrm{mm})^{*}$ & $3.09 \pm 0.56(\mathrm{n}=3)$ & $3.30 \pm 0.39(n=3)$ & $3.26 \pm 0.60(n=3)$ & $3.52 \pm 0.49(\mathrm{n}=3)$ \\
\hline $\mathrm{BSG}(\mathrm{g} / \mathrm{cm})^{*}$ & $1.46 \pm 0.11(\mathrm{n}=3)$ & $1.52 \pm 0.07(\mathrm{n}=3)$ & $1.54 \pm 0.05(\mathrm{n}=3)$ & $1.53 \pm 0.11(\mathrm{n}=3)$ \\
\hline $\mathrm{BMD}(\mathrm{mm} \mathrm{Al})^{*}$ & $3.58 \pm 0.65(n=3)$ & $4.71 \pm 0.99(n=3)$ & $5.04 \pm 0.98(n=3)$ & $5.13 \pm 1.37(\mathrm{n}=3)$ \\
\hline Monthly expenditure ( $\mathrm{R} \$$ ) & nd & 1.86 & 13.7 & 47.7 \\
\hline Daily weight gain & nd & $1.21^{\mathrm{a}}$ & $1.17^{\mathrm{a}}$ & $1.11^{\mathrm{a}}$ \\
\hline
\end{tabular}

${ }^{1}$ During this period they were on a $U$. brizantha pasture.

*Evaluated on 7/28/14 and thereafter on each 30 days after the beginning of the feedlot. $\mathrm{n}=$ number of animals biopsied. \#By the needle test.

(Table V). On that property, for over 10 years, milk production varied between 16 and $19 \mathrm{~kg} / \mathrm{cow} /$ day.

\section{CASE F}

From $1 / 8 / 13$ until 8/17/16 the farm had not used any mineral supplement containing $\mathrm{P}$ and there were no signs of osteophagia or any cows positive in the NT. On $1 / 8 / 13$ the CT, BSG, and BMD were 3.49 , 1.56 and 5.67, respectively (Table V). On 8/17/16 no appearances of osteophagia was reported and no animals were positive in the NT. The CT, BSG, and BMD were 3.54, 1.49 and 5.14, respectively (Table V). On this property, for over three years of evaluation, milk production varied between 18 to $21 \mathrm{~kg} \mathrm{milk/cow} /$ day.

\section{CASE G (EXPERIMENTAL CASE)}

After grazing $U$. brizantha for 49 days with only $\mathrm{NaCl}$ as mineral supplement three bulls were positive on the needle test and results for $\mathrm{CT}, \mathrm{BSG}$ and BMD were 3.09, 1.46 and 3.58, respectively (Table VI). After 30, 60, 90 and 116 days on feedlot no bulls were positive in the needle test. Results for CT, BD and BMD were increased for all groups. P supplementation for Nellore bulls, fed high proportions of concentrate during the feedlot period, resulted in no benefits on daily weight gain and or chemical and physical properties of their bones (Table VI).

As expected, the NT caused minimal discomfort to cattle, with no visual changes in behavior or alterations on the site of incision of the needle. The utilization of the NT allowed herds to be characterized according to their $\mathrm{P}$ status as defined by history, clinical examination (e.g. clinical or subclinical deficiency) and by the relationship between NTs scores versus bone parameters (Figures 1, 2 and 3).

\section{DISCUSSION}

Cattle that showed sub-clinical or clinical $\mathrm{P}$ deficiency responded to a new $\mathrm{P}$ supplementation scheme (e.g. increase of P levels in supplement) both by clinical signs and changing NT results. Results were compared with alterations in bone parameters (CT, BSG and BMD; Figures 1, 2 and 3 ) or on animal performance (e.g. fertility rate, daily weight gain or milk production) in order 


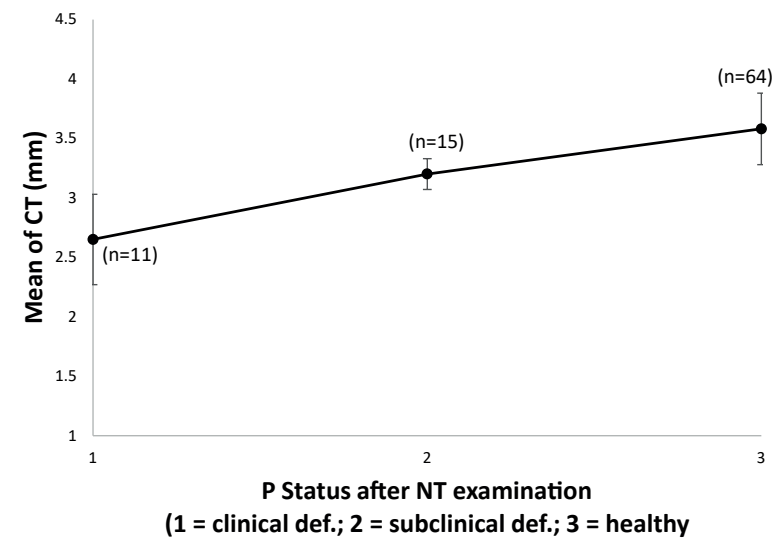

Figure 1 - Relationship between cortical thickness (CT) and NT scores.

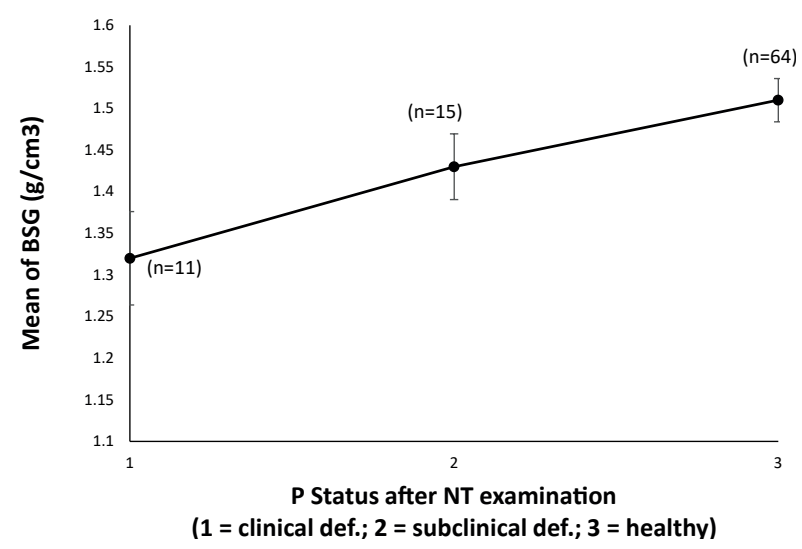

Figure 2 - Relationship between bone specific gravity (BSG) and NT scores.

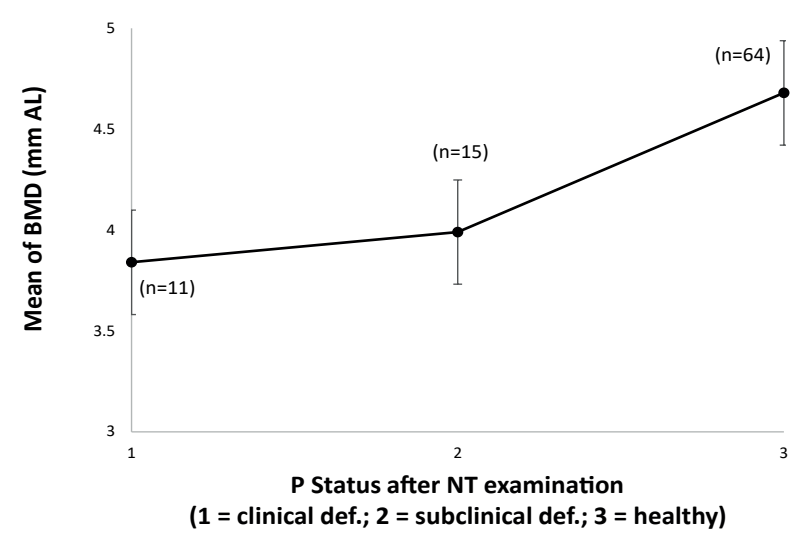

Figure 3 - Relationship between bone mineral density (BMD) and NT scores.

to assess the reliability of the methodology. For example, in property A where there were cases of osteophagia and deaths most likely related with botulism, the elevation of $\mathrm{P}$ in the supplement (from 13.3 to $28 \mathrm{~g} \mathrm{P} / \mathrm{kg}$ ) resulted in improvements of bone parameters and eradication of NT positive cows after five months of use of higher levels of $\mathrm{P}$ in the supplement. However, reduction to $21 \mathrm{~g}$ $\mathrm{P} / \mathrm{kg}$ resulted in 5 to $7 \%$ of cows being positive in the NT after seven months (Table I). Therefore, the level of $\mathrm{P}$ in the supplement was raised again back to $28 \mathrm{~g} / \mathrm{kg}$ and no more NT positive cases were detected (Table I). A similar observation was made in case $G$ in which three bulls were NT positive after not receiving $\mathrm{P}$ via supplement in the preliminary experimental period for 49 days, but turned negative in the first NT made 30 days after being confined with a high grain diet rich in P (Table VI). After 116 days on a feedlot with a diet of high proportion of grains no bulls were positive in the needle test. On property C where no animals performed osteophagia whilst receiving a supplement with $75 \mathrm{~g} \mathrm{P} / \mathrm{kg}, 12.5 \%$ of cows returned positive NT results after 16 months receiving exclusively $\mathrm{NaCl}$. Further evaluation of the dietary management utilized by the farmer led to the conclusion that a P imbalance could have resulted from high use of citrus pulp (known to be very high in $\mathrm{Ca}$ ) which most likely increased drastically the Ca intake. As previously described by Field et al. (1975) and Wan Zahari et al. (1990) high dietary calcium in the diet $(>0.80$ $\%$ ) exacerbates phosphorus deprivation in sheep. Excess calcium tends to form insoluble complexes with dietary $\mathrm{P}$ in the rumen leading to elevated faecal $\mathrm{P}$ elimination. On farm $\mathrm{C}$ we estimated a dietary calcium level of $0.87 \%$. Probably this concentration could have exacerbated faecal $\mathrm{P}$ losses resulting in a mobilization of $\mathrm{P}$ from the bones to the blood, leading to bone rarefaction and to positive NT cases. In case D increased soil fertility from previous fertilizations used for plantation of cowpea and okra is likely the cause for higher P contents in forages produced in the same area. Integrated crop-livestock systems (ICLS) have the advantage to require zero or lower 
P levels in mineral supplements for cattle since higher $\mathrm{P}$ contents can be found in the composition of forage as a result of the use of fertilizers in intensive crop production. This ICLS can significantly reduce costs with $\mathrm{P}$ supplementation of cattle in Brazil.

For all scenarios described in this study, the NT allowed a consistent assessment of the P status of the herd in comparison with established methods (Figures 1, 2 and 3), as previously suggested by Malafaia et al. (2014). Farms E and F adopted the use of zero $\mathrm{P}$ supplementation and no cows were positive in the NT or presented signs of osteophagia throughout the long experimental period. On both farms, milk production averaged between 16 and 21 $\mathrm{kg}$ /day and cows had an average fertility rate above $73 \%$. That was most likely due to supplementation of grains and their by-products that are naturally high in $\mathrm{P}$ allowing health and good performance without addition of $\mathrm{P}$. Paradoxically this zero $\mathrm{P}$ supplementation approach is not in accordance with some recommendations of $\mathrm{P}$ dietary management as provided in AFRC (1993) or the NRC (2001).

For diagnosing $\mathrm{P}$ deficiency in cattle the exclusive interpretation of soil analysis is inappropriate because it could lead to errors related to sampling in the field and chemical interferences between minerals in the soil. It is important to consider that not all of the $\mathrm{P}$ in the soils is available for plants; there are several factors influencing assimilation such as $\mathrm{pH}$ and chemical presentation of the element in the soil. The analytical method (extractants used) where the analysis will be done is another cause of differences between two laboratories. Blood samples are readily obtainable, but results about the P status have to be interpreted with caution as they can be influenced by physiological state (growth, lactation and late pregnancy), stress, dehydration, exercise, and in particular after a short period of P feeding, for example forage that grows after first rainfall can cause a raise in plasma inorganic $\mathrm{P}$ levels even in
P deficient animals (Tokarnia et al. 2010). As P in whole blood is found largely in phospholipids in erythrocytes, incorrect handling and storage of samples may cause haemolysis and produce erroneous results. Pasture samples are far from ideal for assessing the $\mathrm{P}$ status of grazing animals because hand plucked samples do not adequately represent the forage ingested (Read et al. 1986). This problem becomes especially predominant in natural or naturalized grassland areas and can lead to large differences. The evaluation of the $\% \mathrm{P}$ in bone ash, CT, BSG and BMD requires the use of rib biopsies, which are invasive procedures (Malafaia et al. 2017) and requires postoperative care which can complicate routine farm work specifically under extensive livestock conditions, which are predominant in Brazil. According to Jackson et al. (2012) current dietary P status (deficient or adequate) can also be obtained from analyses of the faeces of cattle, which are grazing tropical pastures. According to this method, cattle that are being fed $\mathrm{P}$ supplement, need to have the supplement withdrawn for a week (preferably two weeks) to allow faecal $\mathrm{P}$ concentration to return to lower levels, as if there was absence of $\mathrm{P}$ in the supplement. Faecal samples must be collected from the top of a fresh faecal pile leaving the part touching the soil behind in order to avoid contamination. To find a standard faecal $P$ value that characterizes a deficient herd and to define if the deficiency characterized by that value is of a clinical or a subclinical type there are two important aspects to be considered before using this methodology. In Australia the diagnosis of P-deficient or healthy cattle is based on estimates for the metabolisable energy (ME) of the diet and the faecal $\mathrm{P}$ values obtained from near infrared spectroscopy (Jackson et al. 2012).

The ratio of faecal P:Diet ME (mg P/kg faecal DM divided by the diet ME) is calculated based on those variables. Estimates of ME in tropical pastures of Brazil are difficult to obtain because the faecal NIR equations were not developed in 
similar scenarios as in Australia. Therefore this methodology is still not feasible for use in Brazil. A database obtained with cattle (P-deficient or not) grazing tropical forages on different regions of Brazil resulted on a moderate coefficient of determination $\left(\mathrm{R}^{2}\right)$ of 0.68 between both forage and faecal $\mathrm{P}$ concentration. However, a lower relationship $\left(\mathrm{R}^{2}=0.35\right)$ was found for P-deficient buffaloes grazing tropical forage on Pará state (P. Malafaia, unpublished data).

On the other hand the NT is relatively simple and fast. Once an animal is restrained in the crush a single operator needs less than one minute to perform a bone resistance measurement. It would take 5 to 10 minutes and two operators to perform bone densitometry by single photon absorptiometry (SPA) (Murray et al. 1994). In addition over 60 minutes warm-up time is required for the SPA instrument and it is needed a known standard bone
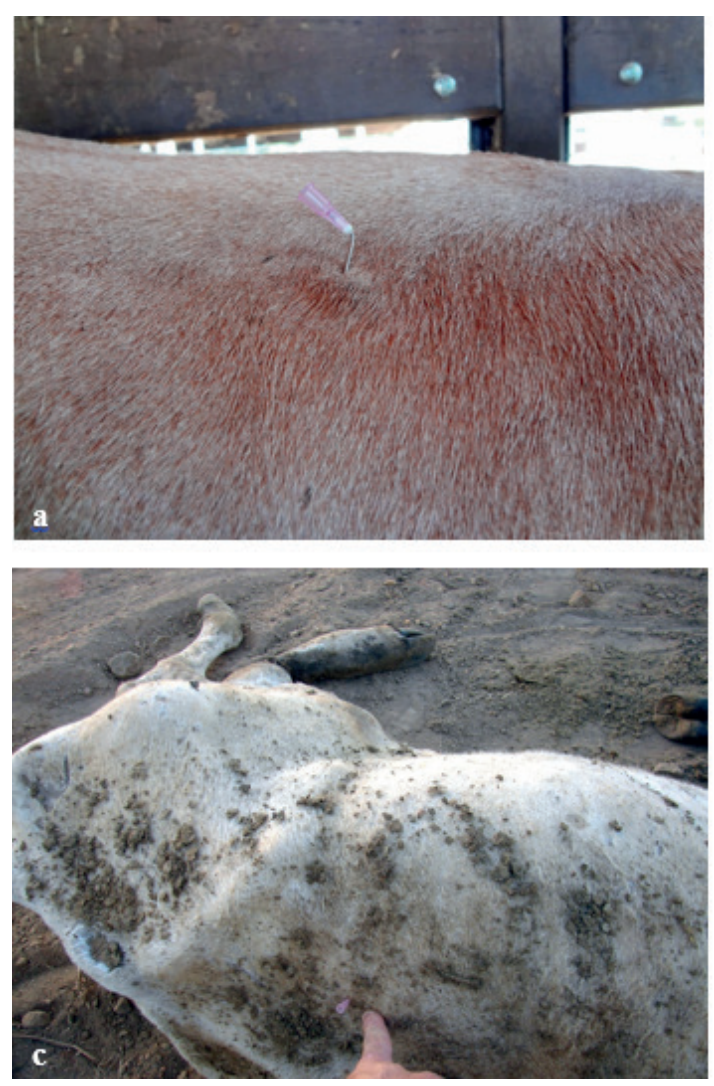

density between animals. Ambient temperatures can cause further instability in SPA measurements (Murray et al. 1994). The high cost of the SPA device can make it unfeasible for developing countries like Brazil.

In summary, we believe that none of the tests or exams that are currently available could be considered as an independent gold standard to evaluate $\mathrm{P}$ status adequacy. Most methods are not sensitive enough for the detection of subclinical $\mathrm{P}$ deficiency and should be used in combination with other tests and a series of best practice protocols. From all methodologies cited above the NT seemed to be the fastest, most reliable, easiest to perform and the least expensive procedure for the assessment of P deficiency of herds in the field. Despite being subjective the NT indicates clearly the existence of three patterns of bone resistance in the TP of the lumbar vertebrae. When TP were
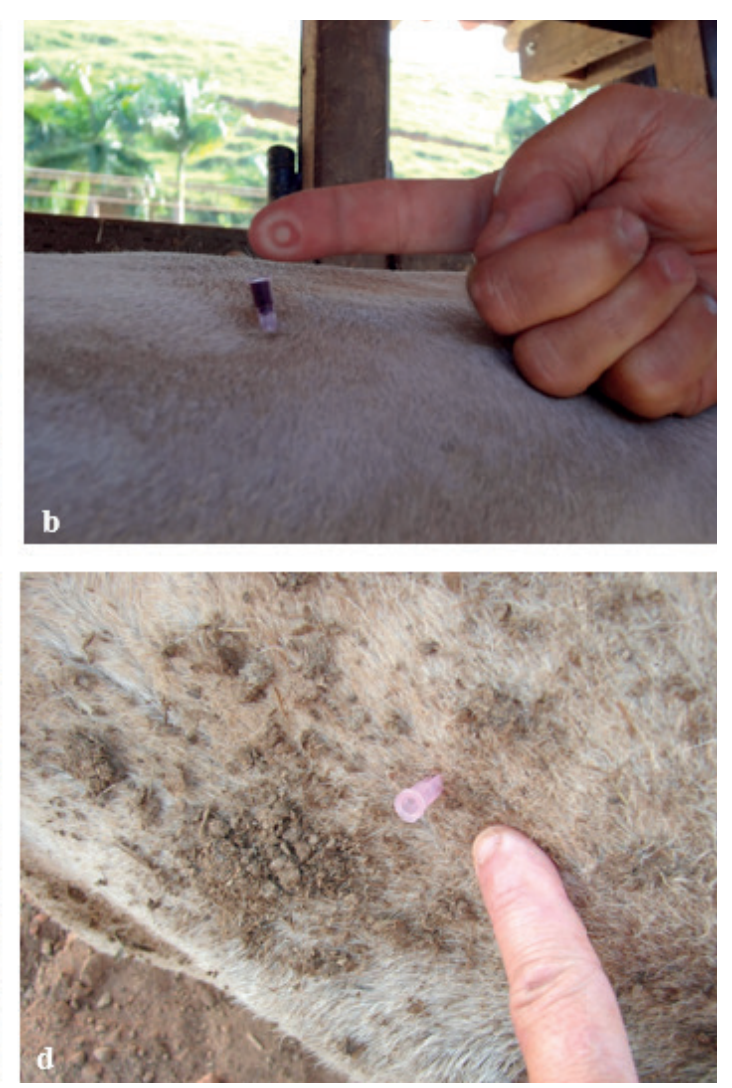

Figure 4 - Cattle with no P defficiency (a), with subclinical P defficiency (b) and with clinical defficiency demonstrated by the NT (c and d). Right metatarsus fractured when unloaded from truck. 

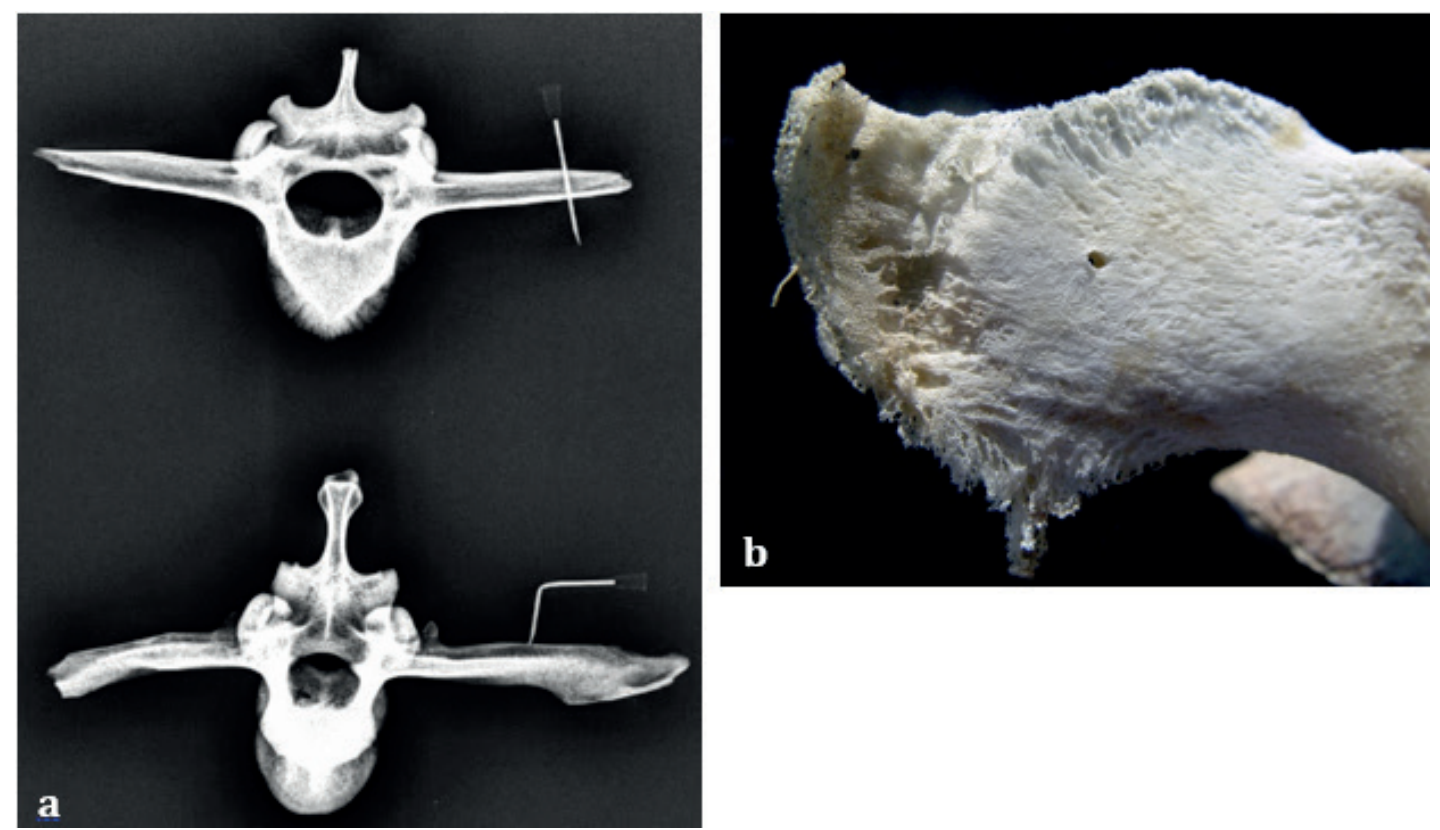

Figure 5 - a. Radiography of the lumbar vertebrae of a positive (top left) and a negative cattle (bottom left) for the needle test. b. Lumbar vertebrae showing the hole left by the needle and the softer bone in the extremity (courtesy of Prof. Diomedes Barbosa, UFPA). All vertebrae were collected after necropsies.

impenetrable and resulted in warping of the needle we could conclude that cattle were healthy for $\mathrm{P}$ status (Figure 4a and Figure 5a bottom). Cattle with subclinical deficiency of $\mathrm{P}$ showed some resistance to the penetration resulting in greater effort by the operator to pierce the TP and leaving a pronounced mark on the operator`s finger (Figure 4b). Minimal resistance to penetration indicated clinical $\mathrm{P}$ deficiency; in this case the needle went through two layers of the bone with little effort (Figure 4c, d and Figure 5a top). It is important to emphasize the need to perform the NT in cattle with more than $300 \mathrm{~kg}$ and on half of the length of the transverse process of the vertebrae $\mathrm{L}_{2}$ or $\mathrm{L}_{3}$ (Figure $5 \mathrm{a}$ bottom), as the extremity of the TP has a softer bone (Figure 5b), which can let the needle to pierce through quickly, without resistance, leading to false positive results.

Based on case studies presented in this paper we recommend changes in $\mathrm{P}$ concentrations in mineral supplements with increments or reductions in the order of 20 or $10 \mathrm{~g} \mathrm{P} / \mathrm{kg}$ and assessment of the herd using the NT should be performed every two months using a representative sample of cattle weighing more than $300 \mathrm{~kg}$ of body weight. For example, on a technically assisted farm that uses a supplement with $60 \mathrm{~g} \mathrm{P} / \mathrm{kg}$, after interpretation of the herd history, a representative number of cattle should be submitted to clinical examination and NT performed. If the herd is not $\mathrm{P}$ deficient a reduction to $40 \mathrm{~g} \mathrm{P} / \mathrm{kg}$ could be initiated as long as animals were constantly monitored during visits scheduled for every two months when a new NT would be performed. If all cows are negative in the NT the professional can suggest a new reduction to $20 \mathrm{~g} \mathrm{P} / \mathrm{kg}$. If some cows are positive an increase is suggested to $50 \mathrm{~g} \mathrm{P} / \mathrm{kg}$ until further evaluation two months later.

It is important to emphasize that under Brazilian conditions the correct utilization of a selective mineral supplement should be based on a constant technical assistance on farms by professionals with solid knowledge on mineral deficiencies and its correction procedures (Malafaia et al. 2004, 2014). It is not just the correct diagnosis 
of a mineral deficiency that is in question but also an adequate prophylaxis, for example via supplementation, which can cause even higher costs if done improperly. Therefore, the use of a selective mineral supplement is not recommended for a farm that is not assisted by professionals. In the present study, all farms had veterinary and nutritional assistance during experimental periods.

Although the NT is a minimally invasive procedure, during long years of this study we performed hundreds of NTs and we did not see any problem with the animals (e.g. abscesses, myiasis, bleeding).

The NT, as a point-of-care test, has to be adopted as a complementary exam to the diagnosis of different stages of P deficiency in cattle and not as a single, independent test. If used indiscriminately, without technical and clinical follow-up within the herd it could lead to misleading results, which in turn can cause inadequate $\mathrm{P}$ supplementation with the potential to negatively impact on the reproductive performance or weight gain. This simple and straightforward point-of-care test is a useful tool to assist technicians and producers to avoid costly expenses for unnecessary P supplementation.

\section{CONCLUSIONS}

Decades of studies about mineral deficiency indicate that recommendations to use of standard formulas with a sole $\mathrm{P}$ concentration are not adequate for cattle grazing in distinct regions of Brazil. Ideally, each property should seek professional assistance to find the most adequate mineral formula since the concentration of $\mathrm{P}$ in mineral mixtures could vary from zero up to high levels. Results of this multiple case study show that the NT is an important tool to assist the evaluation of $\mathrm{P}$ adequacy as long as it is performed by a trained professional and associated with clinical assessments of the herd. The NT can be performed on farms, in vivo, in a fast and simple way and most importantly at a very low cost. The adequate use of the NT can lead to considerable savings and $\mathrm{P}$, a very important mineral in grazing production systems in tropical regions.

\section{ACKNOWLEDGMENTS}

The authors wish to thank all farmers for the use of their properties and herds to carry out the series of case studies and to Robert M. Boddey (Embrapa Agrobiology) and Axel Colling (CSIRO - AAHL) for valuable suggestions and reviewing the English version of the manuscript.

\section{REFERENCES}

AFRC. 1993. Energy and Protein Requirements of Ruminants. CAB International, UK, $159 \mathrm{p}$.

COATES DB, DIXON RM, MAYER RJ AND MURRAY RM. 2015. Validation of single photon absorptiometry for onfarm measurement of density and mineral content of tail bone in cattle. Anim Prod Sci 56: 2054-2059.

EDMONDSON AJ, LEAN IJ, WEAVER CO, FARVER T AND WEBSTER G. 1989. A body condition scoring chart for Holstein dairy cows. J Dairy Sci 72: 68-78.

FIELD AC, SUTTLE NF AND NISBET DI. 1975. Effects of diets low in calcium and phosphorus on the development of growing lambs. J Agric Sci 85: 435-442.

JACKSON D, ROLFE J, ENGLISH B, HOLMES B, MATTHEWS R, DIXON R, SMITH P AND MACDONALD N. 2012. Phosphorus management of beef cattle in northern Australia. Partridge I (Ed), Meat \& Livestock Australia Limited, 43 p.

LITTLE DA. 1972. Bone biopsy in cattle and sheep for studies of phosphorus status. Aust Vet J 48: 668-670.

LITTLE DA, ROBINSON PJ, PLAYNE MJ AND HAYDOCK KP. 1971. Factors affecting blood inorganic phosphorus determinations in cattle. Aust Vet J 47: 153-156.

MALAFAIA P, MAGNOLI COSTA R, BRITO MF, PEIXOTO PV, BARBOSA JD, TOKARNIA CH AND DÖBEREINER J. 2014. Equívocos arraigados no meio pecuário sobre deficiências e suplementação minerais em bovinos no Brasil. Pesq Vet Bras 34: 244-249.

MALAFAIA P, PEIXOTO PV, GONÇALVES JCS, MOREIRA AL, COSTA DPB AND CORREA WS. 2004. Ganho de peso e custos em bovinos de corte submetidos a dois tipos de suplementos minerais. Pesq Vet Bras 24: 160-164.

MALAFAIA P, SALCEDO YTG, USCATEGUI RAR, SOUZA VCS, COSTA DFA AND BERCHIELLI TT. 2017. A simple and fast sampling method for chemical analyses and densitometry of bones through rib biopsies in cattle. Pesq Vet Bras 37: 31-35. 
MURRAY RM, HEARD RW, TIDDY R, BONIFACE AN AND COATES DB. 1994. Tail-bone densitometry as a technique for measuring bone mineral status in cattle. Proc Aust Soc Anim Prod 20: 325-28.

NICHOLSON MJ AND BUTTERWORTH MH. 1986. A guide to condition scoring of zebu cattle. International Livestock Centre for Africa, Addis Ababa, $41 \mathrm{p}$.

NRC - NUTRIENT REQUIREMENTS OF DAIRY CATTLE. 2001. $7^{\text {th }}$ ed. National Research Council, National Academy Press, DC, $381 \mathrm{p}$.

READ MVP, ENGELS EAN AND SMITH WA. 1986. Phosphorus and the grazing ruminant. Blood and faecal grab samples as indicators of the P status of cattle. S Afr J Anim Sci 16: 18-22.

SOUZA VC, MALAFAIA P, GRANJA-SALCEDO YT, VIEIRA BR, GOMES RS, COSTA DFA, NEGRÃO JA, SHIMANO AC AND BERCHIELLI TT. 2017. Effects of phosphorus supplementation in high-grain diets on blood, chemical and physical parameters of bones of feedlot Nellore bulls. Anim Prod Sci. Doi: 10.1071/AN17003.
SOUZA VC, MALAFAIA P, VIEIRA BR, GRANJASALCEDO YT AND BERCHIELLI TT. 2016. Phosphorus supplementation with or without other minerals, ionophore and antibiotic did not affect performance of Nellore bulls receiving high-grain diets, but increased phosphorus excretion and dietary costs. Anim Prod Sci. Doi: 10.1071/ AN16420.

SUTTLE NF. 2010. Mineral Nutrition of Livestock. $4^{\text {th }}$ ed. CABI Publishing, UK, 614 p.

TOKARNIA CH AND DÖBEREINER J. 1973. Diseases caused by mineral deficiencies in cattle raised under range conditions in Brazil, a review. Pesq Agrop Bras 8(Suppl.): $1-6$.

TOKARNIA CH, PEIXOTO PV, BARBOSA JD, BRITO MF AND DÖBEREINER J. 2010. Deficiências Minerais em Animais de Produção. Helianthus, Rio de Janeiro, 191 p.

WAN ZAHARI M, THOMPSON JK, SCOTT D AND BUCHAN W. 1990. The dietary requirements of calcium and phosphorus for growing lambs. Anim Prod 50: 301308 . 